\title{
ASSESSMENT OF THE KNOWLEDGE OF NUTRITIONAL RECOMMENDATIONS AND WAY OF NUTRITION IN VEGETARIANS AND VEGANS
}

\author{
Sandra Marciniak ${ }^{1}$ Ewa Lange ${ }^{1}$, Wacław Laskowski ${ }^{1}$
}

${ }^{1}$ Warsaw University of Life Sciences (SGGW), Institute of Human Nutrition Sciences, Faculty of Human Nutrition, Department of Dietetics Warsaw, Poland

\begin{abstract}
Background. People following a vegetarian diet can obtain all the essential nutrients from a variety of foods. Among the nutrients, protein, iron, calcium, zinc, and vitamins B12 and D3 require special attention.

Objective. To assess the knowledge of dietary recommendations among different groups of vegetarians and the diet they follow.

Material and methods. The study involved a total of 390 subjects ( 360 women and 30 men), aged $18-60$ years, who were following different vegetarian diets. The study was conducted in November 2020 via Facebook using the Computerassisted web interviewing (CAWI) method. Participation in the study was voluntary and anonymous, and sample selection was intentional (participants were members of groups for vegetarians in Facebook). Statistical analysis was carried out using the Chi2 test, using Statistica 13.3 (at $\mathrm{p}=0.05$ ).

Results. To develop the results, the respondents were divided into 4 groups according to their diet: vegan, pescovegetarian, lactovegetarian, and people following other types of diets. The body mass index of nearly $2 / 3$ of the respondents was within the normal range, and more than $80 \%$ of the respondents rated their health as good or very good. An analysis of the frequency of consumption of food products showed that, regardless of the type of vegetarian diet they followed, the participants adhered to the principles of proper nutrition. The respondents who rated their nutritional knowledge as very good were more likely to consume vegetables, fruits, legumes, and whole-grain cereals, and rarely consumed sweet and salty snacks, alcoholic and energizing drinks, or fast food. Vegans more frequently consumed fruits, vegetables, legumes, vegetable fats, and vegetable substitutes for meat and dairy products compared to other vegetarians. In addition to plant products, pesco- and lactovegetarians included selected animal-derived products in their food rations, thus skillfully diversifying the diet. More than $80 \%$ of the vegetarians used dietary supplements, mainly vitamins D and B12.

Conclusions. Regardless of the type of vegetarian diet followed, the participants seemed to be aware of how to balance their diet and the ingredients that should be supplemented, even though a vast majority of them did not consult a diet specialist.
\end{abstract}

Key words: vegetarian diet, nutrition, health

\section{STRESZCZENIE}

Wprowadzenie. Osoby przestrzegające diety wegetariańskiej mogą dostarczać sobie wszystkie potrzebne składniki odżywcze z różnorodnych produktów spożywczych. Składniki wymagające szczególnej uwagi to białko, żelazo, wapń, cynk oraz witaminy B12 i D3.

Cel badań. Ocena znajomości zaleceń żywieniowych i sposobu żywienia wśród różnych grup wegetarian.

Materiały i metody. W badaniu udział wzięło dobrowolnie i anonimowo 390 osób (360 kobiet i 30 mężczyzn) w wieku 18-60 lat, stosujących różne diety wegetariańskie. Badanie było prowadzone w listopadzie 2020 r. za pośrednictwem portalu społecznościowego Facebook z wykorzystaniem metody CAWI (Computer-Assisted Web Interviewing). Dobór próby był celowy (członkowie grup dla wegetarian). Analiza statystyczna została przeprowadzona z wykorzystaniem testu Chi2, przy użyciu programu Statistica 13.3 (przy p=0,05).

Wyniki. Do opracowania wyników respondenci zostali podzieleni na 4 grupy według stosowanej diety: wegańska, pescolub laktoowowegetariańska i inne rodzaje diet. BMI blisko 2/3 respondentów mieściło się w granicach normy, a ponad $80 \%$ oceniło swój stan zdrowia jako dobry lub bardzo dobry. Z analizy częstości spożycia produktów spożywczych wynika, że bez względu na rodzaj diety wegetariańskiej osoby uczestniczące w badaniu przestrzegały zasad prawidłowego żywienia. Respondenci, którzy ocenili swoją wiedzę żywieniową jako bardzo dobra, częściej spożywali warzywa, owoce,

Corresponding author: Ewa Lange, Department of Dietetics, Institute of Human Nutrition Sciences, Faculty of Human Nutrition, Warsaw University of Life Sciences (SGGW), Nowoursynowska 159C, building 32, 02-776 Warsaw, Poland, phone: +48 225937 025, e-mail: ewa_lange@sggw.edu.pl

(C) Copyright by the National Institute of Public Health NIH - National Research Institute 
rośliny strączkowe i produkty zbożowe pełnoziarniste, a rzadko sięgali po produkty tj. słodkie i słone przekąski, napoje alkoholowe i energetyzujące czy żywność typu fast food. Sposób żywienia wegan charakteryzował się częstszym niż innych wegetarian spożyciem owoców, warzyw, roślin strączkowych, tłuszczy roślinnych oraz roślinnych zamienników mięsa i nabiału. Pesco- i laktoowowegetarianie, oprócz produktów roślinnych, planowali w swoich racjach pokarmowych wybrane produkty pochodzenia zwierzęcego, umiejętnie urozmaicając dietę. Ponad $80 \%$ wszystkich wegetarian chętnie sięgało po suplementy diety, w tym głównie witaminę D i B12.

Wnioski. Bez względu na rodzaj diety wegetariańskiej, osoby je stosujące są świadome tego, jak bilansować takie diety i jakie składniki suplementować, mimo, że zdecydowana większość z nich nie konsultuje swojego sposobu żywienia ze specjalistą.

Słowa kluczowe: diety wegetariańskie, sposób żywienia, zdrowie

\section{INTRODUCTION}

A vegetarian diet is defined as a diet that excludes meat and seafood such as fish. According to the American Academy of Nutrition and Dietetics and Dietitians of Canada, which are some of the world's largest dietary associations, properly planned vegetarian diets (such as vegan diet) are beneficial to health and nutritionally appropriate at all stages of life (including pregnancy, lactation, infancy, childhood, adolescence) and may help in the prevention and treatment of certain chronic diseases, including type 2 diabetes, hypertension, and metabolic syndrome. Furthermore, it has been reported that "plant-based diets are more environmentally friendly than diets rich in animal products because they use fewer natural resources and are associated with much less environmental damage" [1, 13]. However, vegetarian and vegan foods may lack several nutrients, including vitamin B12, which is not found in plants, and so people strictly following a vegetarian or vegan diet should consume vitamin B12-enriched foods or take dietary supplements of this vitamin. In addition, supplementation of other nutrients such as iron, zinc, selenium, calcium, iodine, vitamin $\mathrm{D}$, and omega-3 fatty acids, which are more abundant in animal foods than in plant foods, is very important $[10,19]$.

In a systematic review of 12 studies [16] lactoovovegetarians or vegans had higher overall diet quality (4.5-16.4 points higher on the Healthy Eating Index 2010, HEI-2010) compared with nonvegetarians in 9 of 12 studies. Higher HEI-2010 scores for vegetarians were driven by closer adherence to recommendations for fruit, whole grains, seafood and plant protein, and sodium.

A study conducted at the Department of Psychology of the SWPS University in Katowice, Wrocław, and Warsaw (79 people on a meat-free diet and 41 people on a meat-containing diet) [4] indicated that people on a vegan diet had comparatively more knowledge about healthy eating than those following a vegetarian diet or a diet containing meat and other animal products. Participants following a vegan diet for preventative health care seemed to be more knowledgeable about healthy eating.
Vegetarians, especially vegans, are characterized by a lower incidence of hypertension and lower systolic and diastolic blood pressure compared to meat eaters [3]. People who followed different types of vegetarian diets had a lower risk of developing type 2 diabetes compared to those who consumed meat. The mean BMI was the lowest in vegans $\left(23.6 \mathrm{~kg} / \mathrm{m}^{2}\right)$ and was higher in vegetarians $\left(25.7 \mathrm{~kg} / \mathrm{m}^{2}\right)$, pescovegetarians $\left(26.3 \mathrm{~kg} / \mathrm{m}^{2}\right)$, semivegetarians $\left(27.3 \mathrm{~kg} / \mathrm{m}^{2}\right)$, and nonvegetarians $\left(28.8 \mathrm{~kg} / \mathrm{m}^{2}\right)$ [25].

In the AHS-2 cohort, vegans were characterized by a $16 \%$ lower risk of all cancers compared to nonvegetarians, while in the EPIC-Oxford study, vegans, vegetarians, and fish eaters had an $11-19 \%$ lower risk. In the AHS-2 cohort, pescovegetarians were identified to have a significantly lower risk of allcause mortality and coronary heart disease, while in the EPIC-Oxford study, fish eaters had a significantly lower risk of mortality from cancers than their nonvegetarian counterparts [23].

Vegetarians also represented a lower risk of ischemic heart disease (IHD) compared to nonvegetarians who were from a similar environment. Moreover, these participants were found to have a lower risk of obesity, diabetes, diverticulitis, and cataract. It appears that the state of health of vegetarians over a longer period of time is generally good, and in case of some diseases the state of health can be even better in vegetarians than in omnivorous [2]. For the most part, the decision to switch to a vegetarian diet is not consulted with a specialist, so despite the undeniable benefits of plantbased diets, severe dietary restrictions and insufficient knowledge about how to balance such diets can cause nutritional deficiencies. Vegetarians who consume less animal-source foods are considered to be a risk group for vitamin B12 deficiency. More often frequencies of vitamin B12 deficiency have been reported in vegans than in vegetarians as well as in individuals who adhere to a vegetarian diet since birth than in those who adopt such a diet later in life. In addition to vitamin B12 deficiency, it is also well known that eliminating all animal products from the diet increases the risk of vitamin D, calcium, long-chain n-3 fatty acids, and zinc deficiencies [11]. Moreover, the pooled results of the systematic review and meta-analysis 
indicated that those on plant-based diets (compared to omnivore population) exhibited lower bone mineral density (BMD) at the lumbar spine and a reduced whole-body BMD. Vegetarian diets, with a deficiency, among others. calcium and vitamin D can compromise overall bone health [12].

However, additional studies are needed, particularly on the long-term impact of diets that exclude all or almost all animal products on the health status of vegetarians and vegans. It is also important to diversify the range of consumed products in order to balance completely vegetarian diets, as well as to be aware of the nutrients that should be paid more attention when planning a menu. For this reason, the present work aimed to assess the knowledge of dietary recommendations among different groups of vegetarians as well as the diet followed by these people.

\section{MATERIALS AND METHODS}

The survey was conducted among 360 women (92\%) and 30 men (8\%), aged $18-60$ years. The participants were following some type of vegetarian diet and were residing in the Polish territory. They were divided into 4 groups depending on the diet used: vegan $(n=89)$, pescovegetarian $(\mathrm{n}=88)$, lactoovovegetarian $(\mathrm{n}=116)$, or any other type $(\mathrm{n}=97)$.

The study was conducted in November 2020 using the Computer-assisted web interviewing (CAWI) method. A proprietary questionnaire was created for the study in Google Forms and made available on online forums for vegetarians and vegans on the Facebook platform. Participation in the study was voluntary and anonymous, and sample selection was intentional. The survey consisted of 2 parts and a metric. The first part, which evaluated the knowledge of the participants about the current dietary recommendations, contained 7 closed one-choice questions and 3 multiple-choice questions. The second part, which focused on the diet and eating behaviors of the participants, included 13 closed one-choice questions, 2 multiple-choice questions, and 1 open short-answer question. For 24 questions, the respondents were asked to choose one answer from 6 variants that characterize the frequency of consumption of individual products: never, 1-3 times a month, once a week, several times a week, once a day, and several times a day. These variants are assigned scores from 0 (for nonconsumption of the product) to 6 (for the most common consumption), respectively. The repeated questions concerned the reasons for the change in the diet, nature of the food consumed, nutritional knowledge, and dietary supplements taken, which were encoded as 1 if the respondents marked the answer or as 0 if no answer was marked. In addition, the nutritional knowledge of the respondents was assessed using selected questions from the edible KomPAN questionnaire used for studying the views and dietary habits of 16- to 65-year-old subjects [8, 9]. The answers obtained for the questions that can have one possible answer were analyzed by creating count and frequency tables and correlation tables, considering characteristics such as the type of diet used or the self-study of dietary knowledge. For correlation tables, a $C h i^{2}$ test was performed to verify if the analyzed characteristics were significantly related, while Cramer's correlation was determined to assess the level of dependency. A linear graph was made based on the frequency of consumption, showing at the same time all average frequencies for all the products tested, and a correlation model was developed based on the constituent variances.

A subjective assessment of the nutritional knowledge of the respondents was performed using Fisher's test in the variance analysis. The materiality level was taken as $0.05 \%$. All statistical analyses were performed using Statistica 13.3 Plus.

\section{RESULTS}

A significant proportion of the participants (almost $75 \%$ ) were young (aged 18-30), while about $18 \%$ were between the ages of 31-40 and the remaining 6\% were 41-60 years old. An overwhelming majority of vegetarians who participated in the study were from large cities (55\%), about $1 / 3$ of the respondents were from medium or small towns, and about $16 \%$ were from rural areas. Almost half of the respondents had higher education, more than $40 \%$ had secondary education (because a large part of the group were students), and about $4 \%$ declared primary, lower secondary, or vocational education.

The BMI of the subjects was not found to be determined by the type of vegetarian diet they followed. It is noteworthy that $3 / 4$ of the vegetarians who took part in the study diet had a normal BMI, while $17 \%$ were overweight or obese, which may result in negative health consequences, such as metabolic syndrome, in the future when additional risk factors develop.

When assessing their health, the respondents most often indicated that it is good (54\%) or very good $(27 \%)$, and when assessing their diet, most people (74\%) declared that they eat well, i.e. in accordance with healthy eating recommendations. With respect to the diet type, pescovegetarians most often rated their health as good, while vegans were most likely, of all groups, to have very good health. A similar relationship was observed for dietary assessment.

The main reason indicated by the participants for changing to a vegetarian diet was ethical, followed by health and environmental considerations. Most 
Table 1. Characteristics of the group of people participating in the survey

\begin{tabular}{|c|c|c|c|c|c|c|}
\hline Parameters & Variants of answers & $\begin{array}{c}\text { Pesco- } \\
\text { vegetarian } \\
\text { diet [\%] }\end{array}$ & $\begin{array}{c}\text { Vegan diet } \\
{[\%]}\end{array}$ & $\begin{array}{c}\text { Lactoovo- } \\
\text { vegetarian } \\
\text { diet }[\%]\end{array}$ & $\begin{array}{c}\text { Different } \\
\text { diet [\%] }\end{array}$ & $\begin{array}{c}\text { Statistical } \\
\text { significance* } \\
\text { p }\end{array}$ \\
\hline Nr of people & $\mathrm{n}$ & 88 & 89 & 116 & 97 & \\
\hline \multirow{4}{*}{ Age } & $18-30$ & 71.59 & 66.29 & 77.59 & 81.44 & \multirow{4}{*}{0.07565} \\
\hline & $31-40$ & 19.32 & 24.72 & 16.38 & 13.40 & \\
\hline & $41-50$ & 7.95 & 3.37 & 5.17 & 4.12 & \\
\hline & $51-60$ & 1.14 & 5.62 & 0.86 & 1.03 & \\
\hline \multirow{3}{*}{ BMI } & $<18.5 \mathrm{~kg} / \mathrm{m}^{2}$ & 22.22 & 19.44 & 25.00 & 33.33 & \multirow{3}{*}{0.61148} \\
\hline & $18.5-24.99 \mathrm{~kg} / \mathrm{m}^{2}$ & 23.26 & 23.26 & 31.25 & 22.22 & \\
\hline & $\geq 25 \mathrm{~kg} / \mathrm{m}^{2}$ & 19.70 & 22.73 & 25.76 & 31.82 & \\
\hline \multirow{5}{*}{ Education } & basic & 0.00 & 2.25 & 0.00 & 0.00 & \multirow{5}{*}{0.60057} \\
\hline & junior high school & 2.27 & 1.12 & 3.45 & 1.04 & \\
\hline & professional & 1.14 & 2.25 & 1.72 & 2.08 & \\
\hline & medium & 38.64 & 37.08 & 43.10 & 42.71 & \\
\hline & higher & 57.95 & 57.30 & 51.72 & 54.17 & \\
\hline \multirow{4}{*}{ Domicile } & village & 17.05 & 13.48 & 17.24 & 14.43 & \multirow{4}{*}{0.30416} \\
\hline & city up to 20,000 residents & 4.55 & 4.49 & 10.34 & 12.37 & \\
\hline & city 20-100 thousand residents & 23.86 & 15.73 & 22.41 & 20.62 & \\
\hline & city over 100,000 residents & 54.55 & 66.29 & 50.00 & 52.58 & \\
\hline \multirow{5}{*}{$\begin{array}{l}\text { Self- } \\
\text { assessment } \\
\text { of health } \\
\text { condition }\end{array}$} & bad & 0.00 & 2.25 & 1.72 & 6.19 & \multirow{5}{*}{0.015} \\
\hline & neither good nor bad & 15.91 & 7.87 & 22.41 & 12.37 & \\
\hline & hard to say & 1.14 & 2.25 & 1.72 & 2.06 & \\
\hline & good & 62.50 & 49.44 & 47.41 & 57.73 & \\
\hline & very good & 20.45 & 38.20 & 26.72 & 21.65 & \\
\hline \multirow{5}{*}{$\begin{array}{l}\text { Reasons for } \\
\text { changing to } \\
\text { a vegetarian } \\
\text { diet }\end{array}$} & health considerations & 47.73 & $71.91 \%$ & 31.90 & 56.70 & 0.00000 \\
\hline & ethical considerations & 70.45 & 84.27 & 80.17 & 53.61 & 0.00001 \\
\hline & environmental considerations & 57.95 & 59.55 & 54.31 & 39.18 & 0.01958 \\
\hline & taste preferences & 37.50 & 28.09 & 34.48 & 35.05 & 0.58797 \\
\hline & another & 3.41 & 10.11 & 5.17 & 2.06 & 0.07338 \\
\hline
\end{tabular}

* Chi ${ }^{2}$ test

respondents gave more than 1 reason for changing their diet (Table 1).

A majority of the subjects consumed, as recommended, usually 3 or 4 meals during the day. More than $75 \%$ of the respondents declared that they tried to eat their meals at regular intervals of 3-4 hours.

Figure 1 shows the average frequency of consumption of each food group by people following different vegetarian diets. It can be observed that regardless of the type of vegetarian diet followed, subjects adhered to most of the principles of proper nutrition. Among the 4 groups, the vegan diet is characterized by the highest intake of vegetables, fruits, legumes, vegetable fats, whole-grain cereal products, seeds, nuts, and vegetable substitutes for dairy and meat, which is most likely due to the exclusion of all zoonotic products (Figure 1).
Among the vegetarians surveyed, $70 \%$ reported that they do not add sugar for hot drinks such as coffee or tea, about $5 \%$ indicated that they used sweeteners, and about $25 \%$ declared that they add 1 or more teaspoons of sugar to their drinks. Most of them (67\%) occasionally (1-3 times a month) consumed meals outside the home, prepared by catering services. A significant problem noted among the subjects was frequent eating between main meals. As many as $78 \%$ of the participants declared that they frequently consumed snacks 1 time a week or more often. The most commonly consumed snacks included fruit $(60 \%)$, nuts, seeds and pips (53\%), and sweets (41\%), which are rich in simple sugars and/or fat (Table 2).

An overwhelming proportion of respondents rated their nutritional knowledge as sufficient (43\%) or good $(36 \%)$, regardless of the diet they used. Figure 2 shows the extent to which the level of nutritional knowledge 


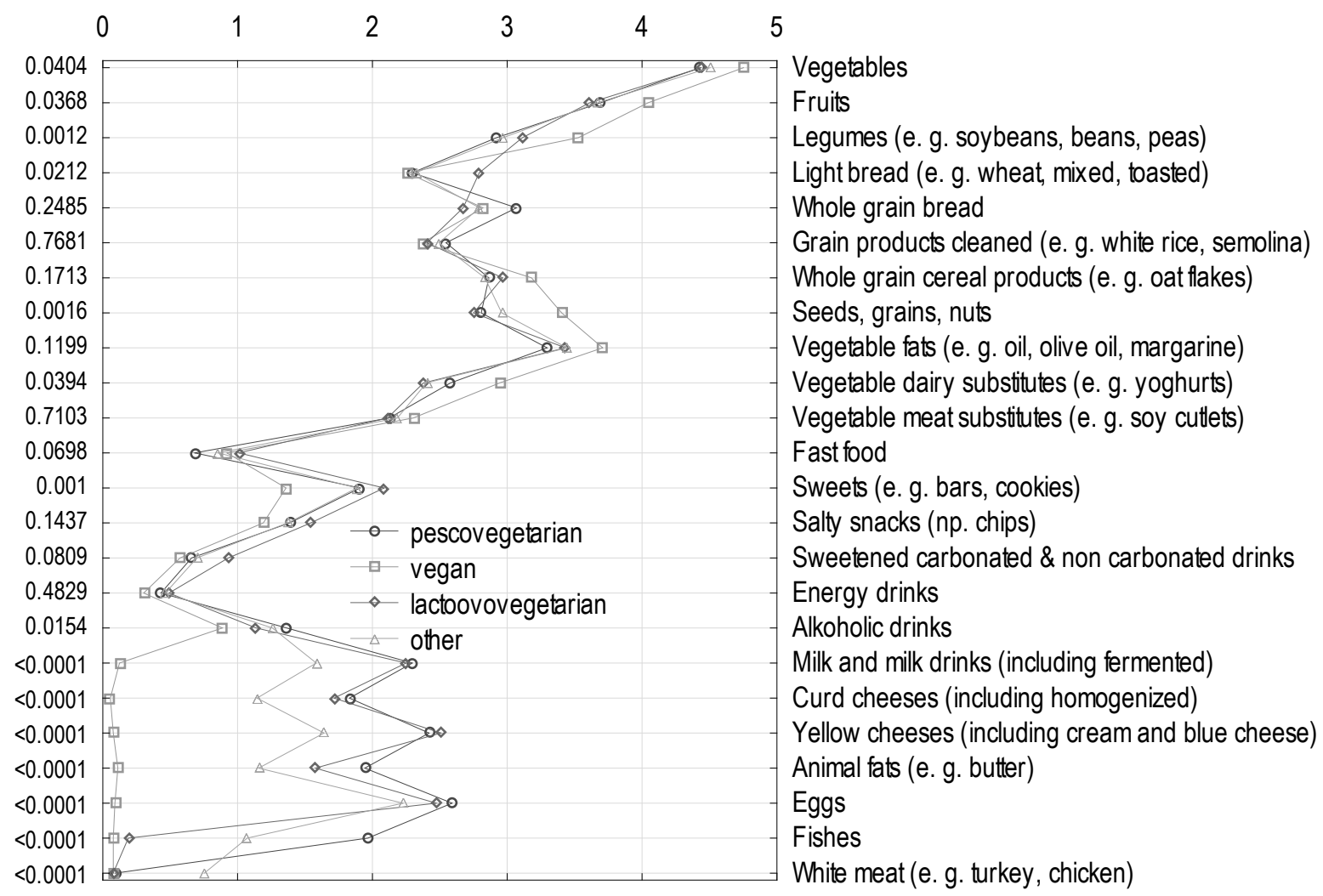

Figure 1. The frequency of consumption of product groups

Explanations: 0 - never, 1 -1-3 times a month, 2 - once a week, 3 - a few times a week, 4 - once a day, 5 - several times a day (horizontal axis) (vertical axis - p value, Fisher's test)

Table 2. Characteristics of the diet of the studied group

\begin{tabular}{|c|c|c|c|c|c|c|}
\hline Parameters & Variants of answers & $\begin{array}{c}\text { Pesco- } \\
\text { vegeta-rian } \\
\text { diet } \\
{[\%]}\end{array}$ & $\begin{array}{l}\text { Vegan } \\
\text { diet } \\
{[\%]}\end{array}$ & $\begin{array}{c}\text { Lactoovo- } \\
\text { vegetarian } \\
\text { diet } \\
{[\%]}\end{array}$ & $\begin{array}{c}\text { Different } \\
\text { diet } \\
{[\%]}\end{array}$ & $\begin{array}{c}\text { Statistical } \\
\text { significance } \\
\text { p* }^{*}\end{array}$ \\
\hline $\mathrm{Nr}$ of people & $\mathrm{n}$ & 88 & 89 & 116 & 97 & \\
\hline \multirow{5}{*}{$\begin{array}{c}\text { Number } \\
\text { of meals } \\
\text { consumed } \\
\text { during the day }\end{array}$} & 1 meal & 0.00 & 1.12 & 0.00 & 0.00 & \multirow{5}{*}{0.00402} \\
\hline & 2 meals & 2.27 & 7.87 & 7.76 & 11.34 & \\
\hline & 3 meals & 27.27 & 31.46 & 36.21 & 29.90 & \\
\hline & 4 meals & 46.59 & 47.19 & 50.86 & 52.58 & \\
\hline & 5 meals and more & 23.86 & 12.36 & 5.17 & 6.19 & \\
\hline \multirow{4}{*}{$\begin{array}{l}\text { Length of } \\
\text { breaks between } \\
\text { meals }\end{array}$} & 1-2 hours & 1.14 & 0.00 & 0.86 & 1.03 & \multirow{4}{*}{0.78965} \\
\hline & 2-3 hours & 25.00 & 29.21 & 23.28 & 31.96 & \\
\hline & 3-4 hours & 65.91 & 60.67 & 63.79 & 53.61 & \\
\hline & 5 hours and more & 7.95 & 10.11 & 12.07 & 13.40 & \\
\hline \multirow{3}{*}{$\begin{array}{l}\text { Eating at } \\
\text { regular times } \\
\text { of the day }\end{array}$} & not & 13.64 & 25.84 & 31.90 & 30.93 & \multirow{3}{*}{0.03544} \\
\hline & Yes. but only some & 56.82 & 50.56 & 52.59 & 51.55 & \\
\hline & Yes. all of them & 29.55 & 23.60 & 15.52 & 17.53 & \\
\hline \multirow{6}{*}{$\begin{array}{l}\text { The frequency } \\
\text { of eating } \\
\text { between meals }\end{array}$} & never & 3.41 & 13.48 & 9.48 & 8.25 & \multirow{6}{*}{0.45538} \\
\hline & 1-3 times a month & 11.36 & 13.48 & 10.34 & 15.46 & \\
\hline & once a week & 19.32 & 14.61 & 22.41 & 16.49 & \\
\hline & a few times a week & 37.50 & 33.71 & 30.17 & 29.90 & \\
\hline & once a day & 18.18 & 19.10 & 14.66 & 22.68 & \\
\hline & several times a day & 10.23 & 5.62 & 12.93 & 7.22 & \\
\hline
\end{tabular}




\begin{tabular}{|c|c|c|c|c|c|c|}
\hline \multirow{3}{*}{$\begin{array}{c}\text { The frequency } \\
\text { of eating meals } \\
\text { away from }\end{array}$} & never & 7.95 & 14.61 & 6.90 & 6.19 & \multirow{3}{*}{0.12390} \\
\cline { 2 - 6 } home & $1-3$ times a month & 62.50 & 65.17 & 73.28 & 64.95 & \\
\cline { 2 - 6 } & once a week & 22.73 & 14.61 & 17.24 & 17.53 & \\
\cline { 2 - 6 } & a few times a week & 5.68 & 5.62 & 1.72 & 11.34 & \\
\cline { 2 - 6 } & several times a day & 1.14 & 0.00 & 0.86 & 0.00 & \\
\hline
\end{tabular}

* $\mathrm{Chi}^{2}$ test

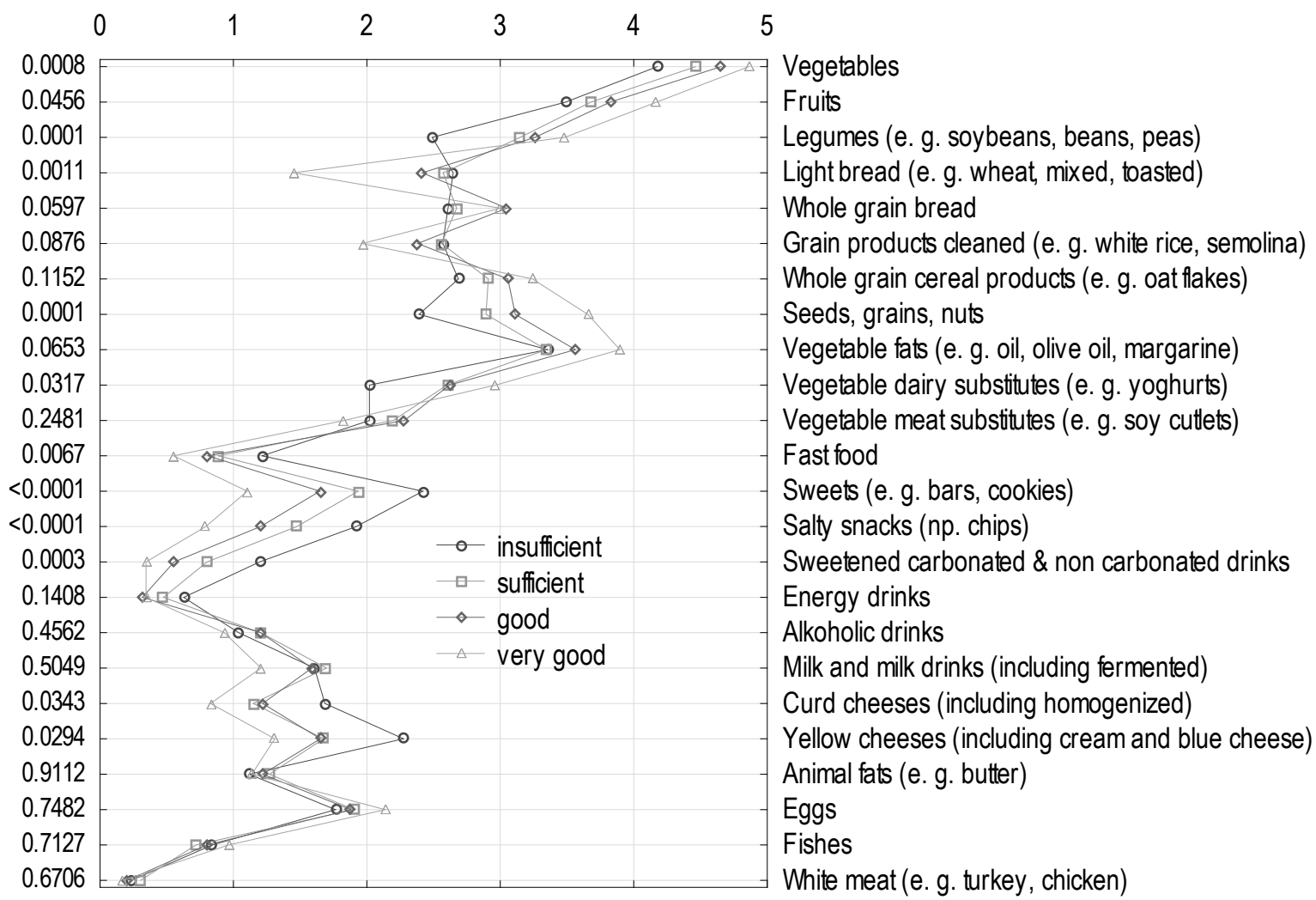

Figure 2. Self-assessment of nutritional knowledge

Explanations: 0 - never, 1 - 1-3 times a month, 2 - once a week, 3 - a few times a week, 4 - once a day, 5 - several times a day (horizontal axis) (vertical axis - p value, Fisher's test)

explains the variation observed in the frequency of consumption of individual products. Respondents assessing their nutritional knowledge as very good showed more healthy behaviors as they more often consumed vegetables, fruits, legumes, and wholegrain cereal products as well as seeds and nuts, while they rarely consumed sweet and salty snacks, light bread, alcoholic beverages and energy drinks, and fast food. On the other hand, people who assessed their knowledge as insufficient least consumed wholesome products such as vegetables, fruits, and whole-grain cereals, and most often consumed products high in salt, simple sugars, and fats (e.g. sweets, cheese) (Figure 2).

The study also showed that vegetarians are very knowledgeable about the products that can substitute meat and other animal-derived products in their diet in terms of protein content. In the multiple-choice question, legumes (i.e. soybean, bean, pea, chickpea, broad bean) were the most frequently selected as a good alternative to meat in terms of nutritional value while being more beneficial to health and the environment.

When asked about the minimum recommended amount of fruit and vegetables consumed per day, $39 \%$ of respondents answered correctly (400 g), while interestingly $44 \%$ indicated a higher value (500 g). A vast majority of respondents $(83 \%)$ correctly indicated the daily ratio of fruit to vegetables (3/4 vegetables; $1 / 4$ fruit). In addition, $75 \%$ were aware of the recommendation that salt intake should be limited to $5 \mathrm{~g}$ per day. This was reflected in reality, as almost $64 \%$ of the participants did not add salt to the prepared foods and sandwiches at the table. Almost $90 \%$ of the respondents were aware that at least 1.5-2 liters of water should be taken per day, and over $57 \%$ followed these recommendations. Regardless of the type of diet followed, vegetarians who participated in the study consumed dietary supplements, mainly vitamins D (36\%) and B12 (27\%). Only 1/4 of the respondents 
declared that they consulted their diet with a doctor, nutritionist, or other professional. No significant differences were noted among the different groups of respondents in terms of the use of dietary supplements or dietary consultation (Table 3).

\section{DISCUSSION}

Among the participants, meat-free diets were most commonly followed by young people aged 18-30 years (about 75\%). A survey conducted by the Ariadna Panel (May 2019; $n=1077$ ) [21] investigating public opinion regarding the attitude of Poles toward plant-based products and dishes confirmed that plantbased diets were particularly popular among young people: $27 \%$ of vegetarians and vegans were under 24 years old, while 25- to 34-year-old respondents accounted for $24 \%$. More than half of the people who follow a vegetarian or vegan diet are under the age of 35. In a survey conducted by the Maczfit analytics team (November-December, 2020; $\mathrm{n}=1415$ ) [20], assessing the nutritional habits of inhabitants from the largest Polish cities (Warsaw, Cracow, Poznan, Lublin, Szczecin, Gdynia, Gdansk, Sopot, Bydgoszcz, Łodz, Wroclaw, and Bialystok), the largest number of respondents who declared following a vegetarian diet were within the age range of $18-25$ years $(71 \%)$, while vegetarians over the age of 46 accounted for $5 \%$ of the respondents. In the study by Pyrzynska [18] on subjects following a vegetarian diet $(n=100)$, the highest number of completed questionnaire was obtained from persons aged 15-34 years, which accounted for as much as $90 \%$ of the respondents.

The results of the present study showed that a significantly higher proportion of respondents following a vegetarian diet were women (92\%). However, the survey conducted by the Ariadna Panel [21] showed that the proportion of women among

Table 3. Characteristics of the diet of the studied group

\begin{tabular}{|c|c|c|c|c|c|c|}
\hline Parameters & Variants of answers & $\begin{array}{l}\text { Pesco- } \\
\text { vegetarian } \\
\text { diet }[\%]\end{array}$ & $\begin{array}{c}\text { Vegan } \\
\text { diet } \\
{[\%]}\end{array}$ & $\begin{array}{l}\text { Lactoovo- } \\
\text { vegetarian } \\
\text { diet }[\%]\end{array}$ & $\begin{array}{l}\text { Different } \\
\text { diet } \\
{[\%]}\end{array}$ & $\begin{array}{c}\text { Statistical } \\
\text { significance } \\
\mathrm{p}^{*}\end{array}$ \\
\hline $\mathrm{Nr}$ of people & $\mathrm{n}$ & 88 & 89 & 116 & 97 & \\
\hline \multirow{4}{*}{$\begin{array}{l}\text { Self- } \\
\text { assessment of } \\
\text { the diet }\end{array}$} & Very bad & 0.00 & 0.00 & 4.31 & 0.00 & \multirow{4}{*}{0.00790} \\
\hline & Bad & 7.95 & 10.11 & 12.07 & 11.34 & \\
\hline & Good & 81.82 & 66.29 & 73.28 & 76.29 & \\
\hline & Very good & 10.23 & 23.60 & 10.34 & 12.37 & \\
\hline \multirow{4}{*}{$\begin{array}{l}\text { Self- } \\
\text { assessment } \\
\text { of nutritional } \\
\text { knowledge }\end{array}$} & Insufficient & 13.64 & 7.87 & 16.38 & 13.40 & \multirow{4}{*}{0.82213} \\
\hline & Sufficient & 40.91 & 41.57 & 45.69 & 43.30 & \\
\hline & Good & 37.50 & 41.57 & 31.90 & 36.08 & \\
\hline & Very good & 7.95 & 8.99 & 6.03 & 7.22 & \\
\hline \multirow{2}{*}{$\begin{array}{l}\text { Consulting } \\
\text { diet with } \\
\text { a specialist }\end{array}$} & Yes & 21.59 & 28.09 & 19.83 & 21.65 & \multirow{2}{*}{0.54254} \\
\hline & No & 78.41 & 71.91 & 80.17 & 78.35 & \\
\hline \multirow{4}{*}{$\begin{array}{l}\text { Amount of } \\
\text { water you } \\
\text { drink during } \\
\text { the day }\end{array}$} & less than 11 & 10.23 & 6.74 & 12.93 & 8.25 & \multirow{4}{*}{0.05259} \\
\hline & $1-1,51$ & 36.36 & 21.35 & 41.38 & 30.93 & \\
\hline & $1,5-21$ & 25.00 & 40.45 & 24.14 & 35.05 & \\
\hline & 21 and more & 28.41 & 31.46 & 2.55 & 25.77 & \\
\hline \multirow{4}{*}{$\begin{array}{c}\text { The habit of } \\
\text { sweetening hot } \\
\text { drinks }\end{array}$} & Not & 69.32 & 78.65 & 66.38 & 65.98 & \multirow{4}{*}{0.28772} \\
\hline & $\begin{array}{l}\text { Yes, I use low energy } \\
\text { sweeteners }\end{array}$ & 7.95 & 2.25 & 4.31 & 7.22 & \\
\hline & $\begin{array}{l}\text { Yes, I sweeten it with one } \\
\text { teaspoon of sugar (or honey) }\end{array}$ & 17.05 & 12.36 & 21.55 & 23.71 & \\
\hline & $\begin{array}{l}\text { Yes, I sweeten with two or } \\
\text { more teaspoons of sugar (or } \\
\text { honey) }\end{array}$ & 5.68 & 6.74 & 7.76 & 3.09 & \\
\hline \multirow{3}{*}{$\begin{array}{l}\text { Custom of } \\
\text { salting ready } \\
\text { meals at the } \\
\text { table }\end{array}$} & Not & 61.36 & 68.54 & 64.66 & 59.79 & \multirow{3}{*}{0.69919} \\
\hline & Yes, but only sometimes & 30.68 & 26.97 & 28.45 & 28.87 & \\
\hline & Yes, I salute most of the dishes & 7.95 & 4.49 & 6.90 & 11.34 & \\
\hline
\end{tabular}

* Chi ${ }^{2}$ test 
nonmeat eaters was low. The gender proportions of this group match with that of the general population of the country. In the Maczfit study [20], it was observed that one in 5 people followed a vegetarian diet (21\%), and among them the majority were women $(86 \%)$.

In the present study, the majority of vegetarians came from large cities (over 100,000 inhabitants) (55\%), about $1 / 3$ from medium or small cities, and about $16 \%$ from rural areas. On the other hand, in the study by Ariadna Panel [21], 8\% of the rural population, accounting for nearly $37 \%$ of all respondents, followed a meatless diet in the month before the study. In small towns with up to 20,000 inhabitants, as many as $12 \%$ of the respondents declared no consumption of meat products, which is the best result among all the surveyed groups. However, among meat eaters, the residents of large cities (over 500,000 inhabitants) were most likely to limit their meat consumption. Nearly half of those living in metropolitan areas declared that they had reduced their meat consumption in the past year.

In the present self-reported survey, a majority of participants had higher education (about 56\%) or high school education (over 40\%), which was due to the fact that a large part of the study group were students. In contrast, in the Ariadna Panel study [21], there were only fewer people among vegetarians and vegans with higher education, which was mainly due to the fact that young-aged respondents constituted a significant part of the study group. In the Maczfit study [19], as in the present study, the respondents who declared as vegetarians were mainly those with higher and secondary education (secondary-50\%, higher-49\%). In the study by Pyrzyńska [18], the vast majority of respondents came from cities and declared secondary or higher education.

In the present study, ethical considerations (72\%) were most frequently cited as the reason for changing to a vegetarian diet, followed by health $(51 \%)$ and environmental concerns (53\%), taste (34\%), and others (5\%). A study conducted by Śliwińska et al. [24] also showed that the most important reasons cited by people for switching to a vegetarian diet were the welfare of animals $(96 \%)$, concern for their own health $(95 \%)$, environmental protection $(74 \%)$, and undesirable taste of meat (74\%). In the present study, most of the respondents declared eating usually 3 or 4 meals a day. More than $75 \%$ tried to eat their meals at regular intervals of 3-4 hours, which is in line with recommendations, while $2 / 3$ of the respondents declared eating between main meals at least once a week. The habit of eating between meals, as well as the type of products consumed, may play a role in maintaining normal body weight, or contribute to the development of overweight or obesity. The study by Schüz et al. [22] indicated that among respondents, snacking accounted for up to $1 / 3$ of daily energy intake and potentially contributed to weight gain. A study by Hampl et al. [6] that analyzed the food intake patterns and BMI among American adults (1756 males, 1511 females) confirmed that consumption of snacks, especially sweetened beverages, remains a problem. However, the direct relationship between total snacking frequency and BMI has not been documented in studies [6, 14].

The present study showed that vegetarians and vegans had a fairly good knowledge of the basic recommendations for proper nutrition, as well as the composition of meat-free diets including components (e.g. calcium, iron) that may be deficient in products that are poorly selected. It is worth noting that the respondents' knowledge of these recommendations was put into practice, as they most frequently consumed vegetables, fruits, and legumes. Whole-grain bread and cereal products were chosen more often than light bread and refined cereal products, and plant-based products were frequently chosen as sources of fat than animal products. A study conducted at the Department of Psychology of the SWPS University in Katowice, Wrocław, and Warsaw (79 people on a meat-free diet and 41 people on a meat-containing diet) [4] indicated that people on a vegan diet had comparatively more knowledge about healthy eating than those following a vegetarian diet or a diet containing meat and other animal products. Participants following a vegan diet for preventative health care seemed to be more knowledgeable about healthy eating. This was also confirmed by the results of the present study, as vegans were more likely to correctly answer questions about dietary components that should be limited (e.g. salt, saturated fatty acids, sugar), the recommended amount of fruits and vegetables, or products that can substitute meat in the diet. A systematic review of 12 studies meeting the inclusion criteria (adults aged $\geq 18$ years, living in Western countries, and following any form of a vegetarian diet or nonvegetarian diet; diet quality measured by an a priori index) [16], which compared the quality of vegetarian and nonvegetarian diets, revealed that lactovegetarians or vegans were characterized by higher overall dietary nutritional value compared with nonvegetarians, which was assumed to partly explain the improvement in their health status. However, more research is needed considering other confounding factors such as awareness of the health effects of meat products and the nutritional value of plant-based products, as well as other nondietary lifestyle characteristics.

This study showed that regardless of the type of vegetarian diet followed, a significant proportion of vegetarians frequently used dietary supplements, mainly vitamin D (36\%) and B12 (27\%), as they were more aware of the risks associated with nutritional 
deficiencies, although only $1 / 4$ of the respondents consulted their diet with a doctor, dietician, or other specialist. A 2017 study conducted by researchers from the Karol Marcinkowski Medical University in Poznań [5], which assessed the prevalence of the use of dietary supplements among vegetarians and traditional eaters, also confirmed that dietary supplements were widely used by vegetarians, compared to those who do not exclude meat and other animal products from their diet. Vitamin B12 supplement was the most commonly taken among vegetarians (nearly $62 \%$ of the respondents). In addition, vitamin D was significantly more often taken by vegetarians than other individuals. In the publication "Normy żywienia dla populacji Polski i ich zastosowanie" [Nutrition standards for the Polish population and their application] from 2020, the authors emphasize that the market currently has plantbased drinks (e.g. soy, oat, and rice drinks), enriched with vitamin B12, which may constitute a source of this vitamin for vegans [7].

Vegetarian diets based on unprocessed and lowprocessed products are characterized by a lower content of saturated fatty acids, cholesterol, and sugar, as well as a higher content of dietary fiber, unsaturated fatty acids, some minerals, vitamins, and phytochemicals, compared to diets including all food groups [26]. Various studies have shown that vegetarians have a lower rate of mortality related to certain chronic diet-related diseases, as well as fewer risk factors for these diseases. This is especially true for obesity, type 2 diabetes, hypertension, IHD, and some cancers [26]. The American Prospective Cohort Study AHS-2, a 5-year cohort study of 73,308 Seventh-Day Adventist men and women, found that vegetarian diets were associated with lower overall mortality and lower mortality related to certain cancers. These associations were more significant in the case of men than in women [15]. The present study showed that the respondents who declared their nutritional knowledge as very good showed more health-promoting behaviors compared to those who rated their knowledge as inadequate. People who were aware of how a well-balanced plant-based diet should be more often consumed vegetables, fruits, legumes, and whole-grain cereal products, as well as seeds and nuts, and rarely reached for products such as sweet and salty snacks, light bread, alcoholic and energy drinks, and fast food. Such plant-based diet may be beneficial to health as long as supplements of vitamins B12 and $\mathrm{D}$ and calcium-fortified dairy alternatives are used, and the health is monitored regularly.

The numerous health benefits associated with a vegetarian diet result not only from the diet but also from lifestyle changes. Vegetarians usually do not smoke, limit or exclude alcohol intake, and are more physically active [26]. However, the present self- reported survey did not include any questions about lifestyle, and hence it is impossible to compare the results with other studies. Moreover, the study sample was small and narrowed down to users of the social networking site Facebook who are members of themed groups for vegetarians and vegans. This purposeful selection of research sample is a limitation, as the results do not reflect the level of nutritional knowledge and diet of all adult vegetarians in Poland, but only that of the users of a certain website who are interested in the topic. In addition, the data on nutritional knowledge and diet were collected through an online questionnaire, and the respondents were not asked about the details of their dietary habits. The questionnaire also did not accurately examine the nutritional value of diets based on current note-taking, and did not include questions about other lifestyle elements such as the use of stimulants, physical activity, quantity and quality of sleep, and mental and social health, which makes it difficult to clearly determine the causal relationships between vegetarian diets and the health status of the subjects. However, the present study can serve as a basis for designing further studies on a larger and more representative group of vegetarians in terms of gender, age, education, and size of the locality of residence, and considering additional non-nutritional factors. Such studies could improve the knowledge on the long-term effects of different types of vegetarian diets on the health status of people following them.

\section{CONCLUSIONS}

The health-promoting quality of the diet followed by vegans, which is characterized by increased intake of vegetables, fruits, whole-grain cereals, pulses, vegetable fats, and seeds and nuts, was related to their declared level of nutritional knowledge.

The level of education and awareness of the adverse effects of intensive animal husbandry on the environment and health of people who consume large amounts of animal products can have a significant impact on the decision to switch to a vegetarian or vegan diet.

Regardless of the type of vegetarian diet, people who followed such a diet were mostly aware of how to balance the rations and the components that should be supplemented, although the vast majority of them did not consult their diet with a specialist.

\section{Acknowledgment}

This work was supported by the Science Club of Dieticians, Warsaw University of Life Sciences (SGGW), Faculty of Human Nutrition, Warsaw, Poland 


\section{Conflict of interest}

The authors declare no conflict of interest.

\section{REFERENCES}

1. American Dietetic Association and Dietitians of Canada: Position of the American Dietetic Association and Dietitians of Canada: Vegetarian diets. Can J. Diet. Pract Res. 2003;64(2):62-81. doi: 10.3148/64.2.2003.62

2. Appleby P.N., Key T.J.: The long-term health of vegetarians and vegans. Proceedings of the Nutrition Society, 2016, 75(3), 287 293. doi: 10.1017/ S0029665115004334

3. Appleby P.N., Davey G.K., Key T.J.: Hypertension and blood pressure among meat eaters, fish eaters, vegetarians and vegans in EPIC-Oxford. Public Health Nutrition, 2002;5(5):645-654. doi: 10.1079/ PHN2002332

4. Brytek-Matera A., Czepczor-Bernat K., Jurzak H., Kornacka M., Kolodziejczyk N.: Strict health-oriented eating patterns (orthorexic eating behaviours) and their connection with a vegetarian and vegan diet. Eat Weight Disord. 2019; Jun;24(3):441-452. doi: 10.1007/s40519018-0563-5.

5. Grzelak T., Suliga K., Pelczyńska M., Sperling M., Czyżewska K: Ocena częstości stosowania suplementów diety wśród wegetarian oraz osób odżywiających się tradycyjnie [Assessment of the frequency of using dietary supplements among vegetarians and people eating traditionally] Probl Hig Epidemiol 2017;98(2):170176 (in Polish)

6. Hampl J.S., Heaton C.L., Taylor C.A.: Snacking patterns influence energy and nutrient intakes but not body mass index. Journal of Human Nutrition and Dietetics, 2003;16:3-11

7. Jarosz M., Rychlik E., Stoś K., Charzewska J: Normy żywienia dla populacji Polski i ich zastosowanie [Nutrition standards for the Polish population and their application] Narodowy Instytut Zdrowia Publicznego Państwowy Zakład Higieny Warszawa 2020 (in Polish)

8. Jeżewska-Zychowicz M., Gawęcki J., Wądołowska L., Czarnocińska J., Galiński G., Koltajtis-Dołowy A., Roszkowski W., Wawrzyniak A., Przybylowicz K., Krusińska B., Hawrysz I., Stowińska M.A., Niedźwiedzka E.: Kwestionariusz do badania poglądów i zwyczajów żywieniowych dla osób w wieku od 16 do 65 lat [Questionnaire to study the views and eating habits of people aged 16 to 65], wersja 1.1 - kwestionariusz administrowany przez ankietera-badacza. Rozdz. 1. (w:) Kwestionariusz do badania poglądów i zwyczajów żywieniowych oraz procedura opracowania danych. [Questionnaire for examining eating views and habits, and data compilation procedure] Gawęcki J. (ed.) Wyd. Komitetu Nauki o Żywieniu Człowieka Polskiej Akademii Nauk, Warszawa, 2018;3-20. dostępny na stronie: http://www.knozc.pan.pl/ (in Polish).

9. Jeżewska-Zychowicz M., Gawęcki J., Wąolowska L., Czarnocińska J., Galiński G., Koltajtis-Dołowy A., Roszkowski W., Wawrzyniak A., Przybylowicz K., Krusińska B., Hawrysz I., Stowińska M.A.,
Niedźwiedzka E.: Kwestionariusz do badania poglądów i zwyczajów żywieniowych dla osób w wieku od 16 do 65 lat [Questionnaire to study the views and eating habits of people aged 16 to 65], wersja 1.2 - kwestionariusz do samodzielnego wypełnienia przez Respondenta. Rozdz. 2. (w:) Kwestionariusz do badania poglądów izwyczajów żywieniowych oraz procedura opracowania danych. [Questionnaire for examining eating views and habits, and data compilation procedure] Red. Gawęcki J. Wyd. Komitetu Nauki o Żywieniu Człowieka Polskiej Akademii Nauk, Warszawa, 2018, 21-33. dostępny na stronie: http://www.knozc.pan.pl/ (in Polish).

10. Langan R.C., Goodbred A.J.: Vitamin B12 Deficiency: Recognition and Management Am Fam Physician. 2017 Sep 15;96(6):384-389

11. Lee Y.P., Loh C.H., Hwang M.J., Lin C.P.: Vitamin B12 deficiency and anemia in 140 Taiwanese female lactovegetarians. J Formos Med Assoc. 2021 Apr 24:S09296646(21)00164-9. doi: 10.1016/j.jfma.2021.04.007. Epub ahead of print. PMID: 33906782.

12. Li T, Li Y, Wu S.: Comparison of human bone mineral densities in subjects on plant-based and omnivorous diets: a systematic review and meta-analysis. Arch Osteoporos. 2021 Jun 18;16(1):95. doi: 10.1007/s11657021-00955-0. PMID: 34145511.

13. Melina V., Craig W., Levin S.: Position of the Academy of Nutrition and Dietetics: Vegetarian diets. J. Acad. Nutr. Diet. 2016;116(12):1970-1980. doi: 10.1016/j. jand.2016.09.025

14. O'Connor L., Brage S., Griffin S.J., Wareham N.J., Forouhi N.G The cross-sectional association between snacking behaviour and measures of adiposity: The Fenland study, UK. Br. J. Nutr. 2015;114:1286-1293, doi: 10.1017/S000711451500269X

15. Orlich M.J., Singh P.N., Sabaté J., Jaceldo-Siegl K., Fan J., Knutsen S., Beeson W.L., Fraser G.E.: Vegetarian dietary patterns and mortality in Adventist Health Study 2 JAMA Intern Med. 2013 Jul 8;173(13):1230-8. doi: 10.1001/jamainternmed.2013.6473.

16. Parker $H W$, Vadiveloo $M K$. Diet quality of vegetarian diets compared with nonvegetarian diets: a systematic review. Nutr Rev. 2019 Mar 1;77(3):144-160. doi: 10.1093/nutrit/nuy067. PMID: 30624697.

17. Pettersen B. J., Anousheh R., Fan J., Jaceldo-Siegl K., Fraser G.F.: Vegetarian diets and blood pressure among white subjects: results from the Adventist Health Study-2 (AHS-2). Public Health Nutrition, 2012;15(10):19091916, doi: 10.1017/S1368980011003454

18. Pyrzyńska E.: Dieta wegetariańska w świetle zasad prawidłowego odżywiania - postawy i zachowania wegetarian w Polsce [A vegetarian diet in the light of the principles. Discovery of nutrition - attitudes and behavior of vegetarians in Poland], Zeszyty Naukowe UEK, 2013;906: 27-36 (in Polish)

19. Protudjer JLP, Mikkelsen A.: Veganism and paediatric food allergy: two increasingly prevalent dietary issues that are challenging when co-occurring BMC Pediatr. 2020 Jul 10;20(1):341. doi: 10.1186/s12887020-02236-0.

20. Raport Maczfit „Wegetarianie i mięsożercy pod lupą!” [Vegetarians and carnivores under the magnifier], 2021 
(https://www.maczfit.pl/blog/wegetarianski-rankingmiast/ dostęp: 17.03) (in Polish)

21. Raport „Roślinniejemy”: „Podsumowanie badań opinii publicznej odnośnie postaw konsumenckich Polaków wobec produktów i dań roślinnych" [Summary of opinions on the consumer attitudes of Poles towards plant-based products and dishes], 2019 r. (https:// roslinniejemy.org/publikacje/postawy-polakowwobec-produktow-roslinnych-raport-z-badan-opiniipublicznej dostęp: 17.03.2021) (in Polish)

22. Schüz B., Revell S., Hills A.P., Schüz N., Ferguson S.G.: Higher BMI is associated with stronger effects of social cues on everyday snacking behaviour Appetite. $2017 \mathrm{Jul}$ 1;114:1-5. doi: 10.1016/j.appet.2017.03.012.

23. Segovia-Siapco G., SabatéJ.: Healthand sustainability outcomes of vegetarian dietary patterns: a revisit of the EPIC-Oxford and the Adventist Health Study-2 cohorts Eur J Clin Nutr. 2019 Jul;72(Suppl 1):60-70. doi: 10.1038/s41430-018-0310z.
24. Śliwińska A., Olszówka M., Pieszko M.: Ocena wiedzy na temat diet wegetariańskich wśród populacji trójmiejskiej [Assessment of knowledge about vegetarian diets in the Tri-City]. Gdański Uniwersytet Medyczny Zeszyty Naukowe Akademii Morskiej w Gdyni, 2014, grudzień, nr 86, (in Polish)

25. Tonstad S., Butler T., Yan R., Fraser G.E.: Type of vegetarian diet, body weight, and prevalence of type 2 diabetes. Diabetes Care 2009;32:791-796.

26. Traczyk I., Jarosz M.: Współczesne poglądy na żywienie wegetariańskie. Żyw Człow Metab. 2010;37:1-6

Received: 07.07.21

Accepted: 15.10 .21

Published online first: 25.10 .2021 